\title{
Application of Flipped Classroom in College English Teaching
}

\author{
Xiaona Dong \\ Applied Technique College, Southwest Petroleum University, Chengdu, China \\ Email: mlbsabc@sina.com
}

Received 24 May 2016; accepted 24 June 2016; published 27 June 2016

Copyright (C) 2016 by author and Scientific Research Publishing Inc.

This work is licensed under the Creative Commons Attribution International License (CC BY).

http://creativecommons.org/licenses/by/4.0/

(c) (i) Open Access

\begin{abstract}
The presentation mode of college English class is not immutable, but it shall realize its unique development pattern under the background of modern science and technology innovation. Considering the complexity of college English itself and many secondary courses, so the college English syllabus particularly emphasizes students' autonomous learning interest and ability in the daily learning. As a result, the experts and scholars within education academic circle both at home and abroad create the teaching mode of "flipped classroom" after long-term research and practice. Although shortcomings still exist in this new teaching model, it will be improved in the development in the future (Bergmann \& Sams, 2012). This paper will analyze briefly from the perspectives of current application situation, problems existed and reflections of "flipped classroom" in college English teaching, hoping to provide theoretical support and practical guidance for Chinese colleges to implement "flipped classroom" practice.
\end{abstract}

\section{Keywords}

Flipped Classroom, College English, English Teaching, Teaching Application, Education Informatization

\section{Introduction}

The new teaching concept of "flipped classroom" is originated in the United States, and the achievements of it in education community have received close attention from education experts and scholars all over the world. But the flipped classroom teaching in China is still in its infancy, so modification and innovation are needed to be implemented in many places. We shall strive to form the "flipped classroom" with Chinese English teaching features gradually in combination with the actual teaching condition in China's college English teaching (Strayer, 2012).

As a public course playing important role in higher education in China, college English is the only way for 
cultivating students' ability in face of the intense competition in the future. The quality of college English classroom teaching will directly affect the overall development of the whole college education, and will also affect the connection of our education talents with international advanced transaction. The application of "flipped classroom" in teaching practice may solve the flaws in traditional education method of English courses in colleges and provide new teaching concepts and ideas for college English education classroom. This great attempt of education innovation will directly act on students, and the largest beneficiaries are college students, providing them with not only the excellent teaching practice experience, but also help them to develop good study habits, which may lay a solid foundation for the life, learning and work in the future. This paper will introduce the concept and significance of "flipped classroom", analyze the current application situation and existing problems of "flipped classroom", and then give suggested measures on "flipped classroom".

\section{Connotation and Denotation of "Flipped Classroom"}

The concept of "flipped classroom" originally comes from America in 2000, which is also known as "Inverted Classroom". It refers to the reallocation by teachers of the practices within or outside the classroom in actual teaching task, and lays the teaching emphasis on motivating students' autonomous learning interest and exploring ability. This new teaching mode is proposed mainly against the disadvantages of traditional teaching method. With this teaching method, teachers can give the power of initiative to students, and help students to focus on the learning of basic items, as well as discover and solve problems in the benign interaction between teachers and students, and jointly cope with the challenges inside and outside the classroom teaching, so as to help students convert the knowledge acquired in the class effectively to apply their knowledge into practice.

One of the characteristic of this method is that teachers do not impart relevant information in the valuable class time, but to distribute the information to the student individual or group for autonomous learning and exploring. The students or group that has received task may complete such learning links as searching, integration and discussion with today's advanced network information technology, and finally display the information that has been learned in the classroom in a unity manner. At this point, teachers should play a fundamental role in guiding to help the student who is displaying information to complete the information interpretation on the one hand, on the other hand, to cause students to think independently and satisfy their demand for their own personalized learning, changing the original simple teaching method into a vivid and interesting one.

As a product conforms to the college education reform in new era, flipped classroom will overlap with the "blended learning", "inquiry learning" and other teaching methods and tools in terms of meaning, but its purpose is to make learning more flexible and active, and make students participation in teaching stronger. The highly developed Internet technology has provided good conditions for the realization and popularization of "flipped classroom", students can come into contact with the online courses and lectures through Internet, as well as conduct the communication and interaction with teacher and other students in a timely manner, without going to the classroom. Therefore, the implementation and promotion of "flipped classroom" will arouse a series of changes in teachers' role, course mode and management mode, injecting new vitality again for the innovation of Chinese higher education.

\section{Practical Application of "Flipped Classroom" in China's College English Teaching}

English learning consists of "listening, speaking, reading and writing”. The college English course setting in China's colleges mainly concentrates on the college Intensive English, Extensive Reading, Grammar, Listening and Oral English, and the teaching materials generally adopted are the college English series. According to the requirements of college English curriculum syllabus, English teachers need to complete the heavy task of English course within the limited class time. Therefore, domestic education experts and scholars have conducted innovative practice of teaching method conforming to the trend of the times prior to "flipped classroom" having formally entered into Chinese higher education. For example, Shandong Dulangkou Middle School adopted "Dulangkou teaching model" in 1998. The difference between it and the current flipped classroom is that students do not use micro video and online exercises, but use such teaching aids as the guided learning plan, textbooks and workbooks to improve the teaching links (Lv \& He, 2013). Chinese colleges started to implement the autonomous listening system gradually after 2006 to encourage students acquire the English listening resources through various channels to improve English listening effect.

Although certain limitation exists in these bold attempts at the beginning of the practice without getting good 
practice effect, we can see that more and more teachers and students have begun to pay attention to the innovation of education concept, and engaged in improving this teaching method actively. It is certain that the innovative education model of "flipped classroom" conforms to Chinese college students' learning conditions and characteristics, having relatively high advantages, integrity and innovation in terms of teaching idea, teaching goal, implementation means, process control and evaluation measures, which has achieved the organic combination with classroom teaching, and made the interaction inside and outside classroom as well as "online-offline" interaction be realized in students' learning process.

\section{Requirements for Implementing "Flipped Classroom" in Chinese College English Teaching}

As an emerging teaching method, "flipped classroom" shall give consideration to its own teaching characteristics and the specific requirements of Chinese college English teaching in specific practice process. Therefore, specific requirements for implementing "flipped classroom" from the following several aspects:

\subsection{College English Teacher Acts as a Guide}

Different from traditional teaching methods, teacher is a "supporting role" in the "flipped classroom", that is to say, teacher is the guide of classroom teaching content. First of all, this kind of teaching mode requires teachers to change their roles actively, change the traditional education concept and boldly make students dominate the teaching. Second, teachers shall fully understand the needs of students from the perspective of students, and offer special guidance to students using the effective classroom time, to achieve the "individualized teaching". These two changing patterns have proposed higher requirements for college English teachers to complete teaching task, and at the same time, encourage teachers to further integrate and improve various aspects of their ability.

\subsection{College Students Are the Main Body of Teaching}

Under the emerging teaching mode, college students convert to the "main body" of teaching, and this obvious transformation mainly require students to further strengthen their own ability in autonomous learning. There are three links to achieve the material transformation, namely, "pre-class, in-class and after-class". In the link of pre-class, students become the clues and collectors of information, which requires students to collect and deal with relevant information according to the learning tasks required by this class or this stage in advance. In the link of classroom participation, students become the main participants of teaching contents to interact with teachers and classmates effectively and share the collected information, having a deep understanding of the contents need to be mastered in the process of discussion. Students shall make feedback of the learning condition of the first two links in after-class link, find out problems and deficiencies, and take initiative to improve them. The joint propulsion of the three links can not only help students to develop the ability of autonomous learning effectively, but also can cultivate the tacit understanding between students and teachers, to enhance the efficiency of team work (Yu, Yang, \& Cheng, 2009).

\subsection{Give Full Play to the Supporting Role of Internet Positively}

In the present era, the highly developed computers and the Internet technology has provided excellent technical platform for the innovation and development of college education. The realization of "flipped classroom" is mainly based on the characteristics of "highly shared" Internet resources, so the teachers and students can edit and use the education resources anywhere and anytime. Therefore, teachers and students are required to improve their computer and network application ability with emphasis, and skillfully use all kinds of multimedia teaching, to display the course content. In addition, the appropriate design and arrangement of classroom practice and after class practice are required to be made, and answer students' questions in a timely manner, to realize smooth communication between teachers and students. Therefore, network application technology should become a booster of the teaching model of "flipped classroom". Teachers and students should have the awareness to improve their related skills, to lay a solid foundation for effective development of "flipped classroom".

\section{Case Exploration of "Flipped Classroom" in College English Teaching}

After the joint efforts of several generations of education scholars and college students, the "flipped classroom" 
(Zhong, Song, \& Jiao, 2013) has achieved good stage progress in college English teaching classroom. Then, analysis and research of practical application of "flipped classroom” will be made taking Unit 2 Values from College English-Integrated Course as an example, to have a rough idea of the specific implementation steps and curriculum implementation effect.

\subsection{Preparation before Class}

Teachers are required to make sufficient shall preparation before class, and actively guide the students to learn. As for the classroom presentation mode, teachers can select the "PPT structure demonstration method" and "video guidance" to interpret the lesson of "Values". Therefore, teachers need to collect some celebrity quotes and videos as well as books to lead in the text. For example, teachers can put together the videos of a series of "billionaires" to make students conduct the pre-class collection and integration regarding the subject of "value" in their eyes for the effective discussion in classroom.

\subsection{Classroom Discussion}

Teachers can divide the whole classroom design into three links: "text lead in-classroom discussion-classroom effect feedback". While interpreting "Values”, the first 5 - 10 minutes shall be used to lead in the course video and audio, to help students understand teaching background and target on the one hand, and on the other hand to cultivate students' good sense of English, encourage students to read after and imitate, so as to improve English listening and speaking ability. Then teachers can encourage students to discuss the information they have collected in front of the class, for example, what do you think of the value? Does the rich man means a lot of values for the society? What is necessary for you to be a valued man? What is your opinion on those rich but not so "valued" men in life? Teachers should encourage students to discuss the information they have collected and reach a consensus at the end. At the end of the course, teachers can use 15 minutes or so to interpret grammar, vocabulary and writing of the textbook, which can check the classroom effect from students' feedback. Students' ability to use rather than rote-learning shall be trained in this part.

\subsection{After Class Feedback and Questions Answering}

This step will be ignored by many teachers in the actual teaching process of "flipped classroom”. Actually after class feedback and question answering are conductive to help students learn about the problems exist in this emerging teaching method in a timely manner, and accurately grasp the students' problems in the process of participating. This part seems to be redundant, but plays a decisive role in the actual teaching process. For example, in the lesson of "Values", teacher may be unable to explain the text, vocabulary and grammar in detail due to the limited classroom time, moreover, some students may have no sufficient preparation before class, resulting in difficulty for students to grasp the teaching contents. Therefore, teachers are required to communicate with classmates after class to understand the teaching trend in a timely manner.

\section{Conclusion}

As the innovative teaching practice mode under Chinese higher education reform, “flipped classroom” has made outstanding contribution to China's college English education. As for college English teachers, this teaching mode has got rid of the traditional classroom teaching mode, to take full use of the classroom time and resources as well as improve the classroom teaching efficiency; as for the students, they can improve their interest in learning and their autonomous learning abilities. In view of the current situation of China's college English teaching, although differences exist between the development of "flipped classroom" itself and the agreement of China's education practice, it will play its excellent effect through common effort of all sections of society as well as teachers and students. The positive role of "flipped classroom" in college English teaching should not be ignored, which has injected new vitality for the current higher education reform in China.

\section{References}

Bergmann, J., \& Sams, A. (2012). Flip Your Classroom: Reach Every Student in Every Class Every Day (pp. 120-190). Washington DC: International Society for Technology in Education. 
Lv, L. S., \& He, G. D. (2013). Reflection on Influence of Information Technology Based College English Autonomous Learning Mode on Students’ Non-intellectual Factors. Shandong Foreign Language Teaching Journal, No. 4, 160-187.

Strayer, F. J. (2012). How Learning in an Inverted Classroom Influences Cooperation, Innovation and Task Orientation. Learning Environ Research, 15, 171-193. http://dx.doi.org/10.1007/s10984-012-9108-4

Yu, S. Q., Yang, X. M., \& Cheng, G. (2009). Discussion on Learning Resources Design and Sharing in Learning Environment-Concept and Structure of "Learning Cell”. Open Education Research, No. 1, 147-153.

Zhong, X. L., Song, S. Q., \& Jiao, L. Z. (2013). Research on Teaching Design Based on "Flipped Classroom” Concept in Information Environment. Open Education Research, No. 1, 190-264.

\section{Submit or recommend next manuscript to SCIRP and we will provide best service for you:}

Accepting pre-submission inquiries through Email, Facebook, Linkedin, Twitter, etc A wide selection of journals (inclusive of 9 subjects, more than 200 journals)

Providing a 24-hour high-quality service

User-friendly online submission system

Fair and swift peer-review system

Efficient typesetting and proofreading procedure

Display of the result of downloads and visits, as well as the number of cited articles

Maximum dissemination of your research work

Submit your manuscript at: http://papersubmission.scirp.org/ 